\title{
RISK ASSESSMENT OF CHEMICALS IN A TOXICOLOGICAL LABORATORY: A CASE STUDY
}

\section{A. DIMITRIOU ${ }^{1, *}$ H. TSOUKALI ${ }^{2}$}

\author{
${ }^{1}$ Laboratory of Research and Communication for the \\ Environment and the Environmental Education \\ Department of Education Sciences in Pre-School Age \\ Democritus University of Thrace \\ 68100 Alexandroupolis, Greece \\ ${ }^{2}$ Laboratory of Forensic Medicine\& Toxicology \\ School of Medicine, Aristotle University \\ 54124 Thessaloniki, Greece
}

Received: 13/02/06

Accepted: 30/05/06 *to whom all correspondence should be addressed: e-mail: anadim@otenet.gr

\begin{abstract}
The toxicity of a chemical substance in a workplace depends on both its physical and chemical properties, the level of concentration in the breathing air, as well as, the duration of the exposure. In order to ensure healthy conditions at workplace, international organizations, such as the World Health Organization (WHO) and the International Labor Organization (ILO), have instituted upper limits of concentration for several chemicals that could provoke serious problems or disturbances on human health.

The aim of the present paper is the estimation of the concentrations of ethanol, ethyl acetate and chloroform, which are widespread solvents used during routine analyses in a toxicological laboratory.

The monitoring of the solvents at the laboratory was carried out during the summer period of two successive years. The monitoring was focused on the estimation of: a) the meteorological parameters (temperature and air humidity), b) both inhalation and dermal exposure concentrations by using personal air sampling systems, c) the concentrations in the environmental air of the laboratory and d) the concentration in urine samples of the employees. The above-mentioned activities have been achieved through the use of appropriate air samplers which employees were carrying both on the height of inhalation zone and their arms. For the qualitative and quantitative estimation of the concentrations, chemical substances were extracted with the use of carbon sulphide and then by the use of gas chromatographic technique equipped with flame ionization detector. Urine analyses were done by colorimetric techniques.

The results of the monitoring showed concentrations of ethanol, ethyl acetate and chloroform over those instituted for workplaces. In this paper, results of the monitoring are discussed and proposals for ensuring air quality at workplace are suggested.
\end{abstract}

KEYWORDS: Risk assessment, toxicology, laboratory, occupational exposure, ethanol, ethyl acetate, chloroform, gas chromatography.

\section{INTRODUCTION}

During routine analyses in a toxicological laboratory, several chemical substances are used for both qualitative and quantitative purposes. Ethanol, ethyl acetate, as well as, chloroform are the most frequently used solvents in daily analyses in a laboratory of forensic toxicology. As a result, employees might be exposed at concentrations that affect their health.

In order to ensure healthy conditions at workplace, international organizations, such as the World Health Organization (WHO), the International Labor Organization (ILO) as well as the American Conference of Governmental Industrial Hygienists (ACGIH), have instituted upper 
limits of concentration for several chemicals that could provoke serious problems or disturbances on human health. For the most chemical substances at workplace, a threshold limit value (TLV) as a long-term exposure limit for eight working hours is used. The three solvents are considered as toxic ones in cases of heavy use. The occupational standard for ethanol in air is $1000 \mathrm{ppm}\left(1900 \mathrm{mg} \mathrm{m}^{-3}\right)$ on an eight - hour basis when for ethyl acetate and chloroform are $400 \mathrm{ppm}\left(1440 \mathrm{mg} \mathrm{m}^{-3}\right)$ and $10 \mathrm{ppm}\left(49 \mathrm{mg} \mathrm{m}^{-3}\right)$ respectively.

In respect to its toxicity, ethanol at concentrations of $1000 \mathrm{ppm}$ or higher, causes eye and upper respiratory tract irritation, fatigue, headache and sleepiness (ACGIH, 1991; Claytoll and Clayton, 1994). Ethanol's important toxic effects require that the substance first enter the bloodstream. Experiments in humans have shown that the 55 to $60 \%$ of inhaled vapours are absorbed into the bloodstream (Kruhoffer, 1983; Lester and Greenberg, 1951).

Ethyl acetate is CNS (Central Nervous System) depressant and concentrations above 2,000 ppm are anesthetic. Severe over-exposure may lead to weakness, drowsiness, unconsciousness and death. Ethyl acetate is irritating to the eyes, mucous membranes and respiratory tract. Prolonged inhalation can lead to renal or hepatic damage. Prolonged contact may cause skin irritation, dermatitis, conjunctive and corneal irritation (Klaassen, 2001; WHO, 2005).

Exposure to chloroform, leads to headaches, weakness, dizziness, heart problems and hepatic injury (WHO, 2005). The severity of liver injury due to inhaled chloroform is not only influenced by the administered concentration but also by the shape of the exposure profile. Plummer et al. (1990), exposed male black-hooded Wistar rats for 4 weeks to chloroform vapour at a constant concentration $\left(245 \mathrm{mg} \mathrm{m}^{-3} ; 24 \mathrm{~h} \mathrm{day}^{-1} ; 7\right.$ days a week) or at repeated concentrations (1387 $\mathrm{mg} \mathrm{m}^{-3} ; 6 \mathrm{~h} \mathrm{day}^{-1} ; 5$ days a week), with a similar total exposure (154 g $\mathrm{m}^{-3} \mathrm{~h}^{-1}$ ) for the two ways of exposure. Hepatic injury appeared to be more severe in the continuously exposed group, in which micro vesicular fatty change was the most prominent feature, while focal necrosis was a minor feature. Livers of the animals receiving repeated exposures showed only minor injuries in the form of scattered hepatocytes containing small fat droplets and a few foci of liver cell necrosis.

During routine analyses in a laboratory of toxicology, solvents are commonly used in a daily basis. Especially in the Laboratory of Forensic Medicine and Toxicology of the Aristotle University of Thessaloniki, ethanol, ethyl acetate and chloroform are daily used for both quantitative and qualitative routine analyses. This laboratory is authorised for toxicological analyses of biological samples (such as tissues, blood and urine) as well as of material samples (drugs) for quantitative and qualitative estimation of known chemicals substances. Every year about 10,000 analyses are done, which means that, in a daily basis, employees are exposure at various substances including solvents.

The protection of the employees' health is the first priority of the Laboratory. Therefore a project for estimating the exposure levels of ethanol, ethyl acetate and chloroform, which are widespread solvents used during routine analyses in a toxicological laboratory, was performed. The results of this project are presented in this paper.

\section{MATERIALS AND METHOD}

The monitoring of ethanol, ethyl acetate and chloroform at workplace was carried out during the summer period of two successive years (2001 and 2002). The monitoring focused on the estimation of: a) the meteorological parameters (temperature and air humidity), b) both inhalation and dermal exposure concentrations by using personal air sampling systems, c) the concentrations in the environmental air of the laboratory and d) the concentration in urine samples of the employees.

Meteorological parameters were estimated by the use of a digital thermometer and hydrometer.

The monitoring of inhalation and dermal concentrations of ethanol, ethyl acetate and chloroform, has been achieved through sampling onto charcoal tubes, (Diffusion ORSA5 $400 \mathrm{mg}$ ), that are recommended by both the International Organization of Labor (ILO) and the American Council of Governmental Industrial Hygienists (ACGIH).

During personal monitoring, the employees (a man and two women) used to carry personal air samplers both on the height of inhalation zone and their arms during work. Twelve 
personal samplers were collected (two in the inhalation zone and two in arms for each employee).

For the qualitative and quantitative estimation of the concentrations, chemical substances were extracted by the use of carbon sulphide and measured by the use of gas chromatographic technique equipped by flame ionization detector (FID) (Table 1).

Table 1. Gas Chromatography Analysis Conditions

\begin{tabular}{ll}
\hline Column & OV -1 \\
\hline Column Temperature & $60{ }^{\circ} \mathrm{C}$ \\
\hline Injection Temperature & $70{ }^{\circ} \mathrm{C}$ \\
\hline Detector Temperature & $100{ }^{\circ} \mathrm{C}$ \\
\hline Carrier Gas - Flow Rate & Nitrogen $\left(\mathrm{N}_{2}\right)$ at $15 \mathrm{ml} \mathrm{min}^{-1}$ \\
\hline
\end{tabular}

The determination of ethanol, ethyl acetate and chloroform concentration in urine samples of the employees was done by colorimetric techniques (Table 2).

Table 2. Colorimetric technique for the determination of ethyl acetate, ethanol and chloroform in urine samples.

\begin{tabular}{lcc}
\hline Substance & Colorimetric Method & Color \\
\hline Ethanol & $\begin{array}{c}1 \mathrm{ml} \text { urine }+10 \% \mathrm{NaOH} \\
+ \text { lodide }\end{array}$ & Yellow \\
\hline Ethyl acetate & $1 \mathrm{ml}$ urine $+\mathrm{NH}_{4} \mathrm{OH}+\mathrm{FeCl}_{2}$ & Red \\
\hline Chloroform & $\begin{array}{c}1 \mathrm{ml} \text { urine }+1 \mathrm{ml} \mathrm{pyridine} \\
+1 \mathrm{ml} \mathrm{NaOH}\end{array}$ & Reddish \\
& & \\
\hline
\end{tabular}

\section{RESULTS}

Monitoring data are presented in Table 3.

As it is shown on Table 3, both inhalation and dermal concentrations of ethanol and ethyl acetate are below the occupational standard level, that are $1900 \mathrm{mg} \mathrm{m}^{-3}$ and $1440 \mathrm{mg} \mathrm{m}^{-3}$ respectively.

On the contrary, both inhalation and dermal concentration levels of chloroform exceeded slightly occupational standards, that is, $49 \mathrm{mg} \mathrm{m}^{-3}$, during both monitoring period.

Dermal concentration levels of the three solvents are higher than the inhalation ones.

Relating to ethyl acetate, ethanol and chloroform levels in urines samples, the analysis results show no evidence of the presence of these solvents.

\section{DISCUSSION}

Relating occupational exposure to ethanol no reports regarding chronic exposure have been located (WHO, 2005a).

Relating occupational exposure to ethyl acetate in laboratories no reports have been published but several studies regarding its toxicity have been published (WHO, 2005b).

Several studies on chloroform concentrations in laboratories have been published. Levels found by NIOSH in laboratories ranged from 0.5 to $24.9 \mathrm{mg} \mathrm{m}^{-3}$ (Salisbury, 1982). Timeweighted $(4 \mathrm{~h})$ average levels during laboratory practices were $0-375 \mathrm{mg} \mathrm{m}^{-3}$ (Hertlein, 1980). Also, Taketomo \& Grimsrud (1977) reported levels of 2.3-8.6 $\mathrm{mg} \mathrm{m}^{-3}$ in three laboratories in Montana, USA. In an office situated in the same building but distant from the laboratories, levels were similar; this was attributed to transfer through the air-conditioning system. 
Table 3. Monitoring Data

\begin{tabular}{|c|c|c|c|c|}
\hline \multicolumn{5}{|c|}{ First Year } \\
\hline \multirow{2}{*}{\multicolumn{5}{|c|}{$\begin{array}{l}\text { 1. Meteorological Parameters } \\
\text { Temperature }: 37^{\circ} \mathrm{C} \\
\text { Humidity : } 60 \% \\
\text { 2. Exposure Levels }\left(\mathbf{m g ~ m}^{-3}\right)\end{array}$}} \\
\hline & & & & \\
\hline \multicolumn{5}{|c|}{ A. Inhalation Concentrations } \\
\hline Employee & $\begin{array}{l}\text { Working Duration } \\
\text { (hours) }\end{array}$ & Ethanol & Ethyl Acetate & Chloroform \\
\hline A & 4 & 1500 & 1500 & 50 \\
\hline $\mathrm{B}$ & 4 & 1300 & 1200 & 50 \\
\hline $\mathrm{C}$ & 4 & 1400 & 1300 & 50 \\
\hline \multicolumn{5}{|c|}{ B. Dermal Concentrations } \\
\hline Employee & $\begin{array}{l}\text { Working Duration } \\
\text { (hours) }\end{array}$ & Ethanol & Ethyl Acetate & Chloroform \\
\hline A & 4 & 1000 & 1200 & 60 \\
\hline $\mathrm{B}$ & 4 & 1000 & 1200 & 70 \\
\hline $\mathrm{C}$ & 4 & 1200 & 1200 & 70 \\
\hline \multicolumn{5}{|c|}{ Second Year } \\
\hline \multirow{2}{*}{\multicolumn{5}{|c|}{$\begin{array}{l}\text { 1. Meteorological Parameters } \\
\text { Temperature }: 37^{\circ} \mathrm{C}\end{array}$}} \\
\hline & & & & \\
\hline \multicolumn{5}{|c|}{ A. Inhalation Concentrations } \\
\hline Employee & $\begin{array}{l}\text { Working Duration } \\
\text { (hours) }\end{array}$ & Ethanol & Ethyl Acetate & Chloroform \\
\hline A & 8 & 1500 & 1500 & 70 \\
\hline $\mathrm{B}$ & 8 & 1400 & 1400 & 60 \\
\hline C & 8 & 1300 & 1400 & 70 \\
\hline \multicolumn{5}{|c|}{$\begin{array}{c}\text { B. Dermal Concentrations } \\
\end{array}$} \\
\hline Employee & $\begin{array}{l}\begin{array}{l}\text { Working Duration } \\
\text { (hours) }\end{array} \\
\end{array}$ & Ethanol & Ethyl Acetate & Chloroform \\
\hline A & 8 & 1200 & 1200 & 70 \\
\hline B & 8 & 1200 & 1300 & 70 \\
\hline $\mathrm{C}$ & 8 & 1000 & 1300 & 80 \\
\hline
\end{tabular}

The concentrations measured at the toxicological laboratory of the Aristotle University are mostly on accepted levels. Although in order to support personnel, the Laboratory provided them the appropriate personal mask in order to minimize the inhalation levels of solvents during toxicological analysis procedure. The personnel were also informed for the importance of applied personal protection measures and were empowered to apply them.

It has to be reported that in recent years, many solvents have been replaced by solid phase extraction techniques or other instrumental methods. So, both the personnel and the environment are subjected to less solvent exposure.

\section{REFERENCES}

1. American Council of Governmental Industrial Hygienists (ACGIH) (1991). Documentation of the Threshold Limit Values and Biological Exposure Indices, sixth edition.

2. Clayton G. and Clayton F. (1994). Patty 's Industrial Hygiene and Toxicology, fourth edition. New York: John Wiley \& Sons.

3. Hertlein F. (1980) Monitoring airborne contaminants in chemical laboratories, ACS Symp Ser, 120: 215-230, in WHO (1994). Environmental Health Criteria 163 -Chloroform. World Health Organization. Geneva.

4. Klaassen C. (2001) Casarett and Doull's Toxicology. Sixth Ed. New York: Mac-Graw-Hill 
5. Plummer J.L., Hall P. de-la M., Ilsley A.H., Jenner M.A. and Cousins M.J. (1990) Influence of enzyme induction and exposure profile on liver injury due to chlorinated hydrocarbon inhalation, Pharmacol Toxicol, 67, 329-335.

6. Salisbury S. (1982) Health hazard evaluation. Charleston Laboratory (Report No. HETA-81359-1058) in WHO (1994), Environmental Health Criteria 163 -Chloroform. World Health Orgnization. Geneva.

7. Taketomo A.P. and Grimsrud E. (1977) An analysis of halocarbons in the air of several working and living environments. Proc Mont Acad Sci, 37, 128-134. in WHO (1994).

8. WHO (2005a). Environmental Health Criteria 163 -Chloroform. World Health Organization. Geneva. Retrieved from WHO Website: www.who.org (March, 2005).

9. WHO (2005b) WHO Website: www.who.org (March, 2005). 